Article

\title{
Systemic Inequity in Urban Flood Exposure and Damage Compensation
}

\author{
Shifteh Mobini ${ }^{1, *} \mathbb{C}$, Per Becker ${ }^{2,3} \mathbb{C}$, Rolf Larsson ${ }^{1}$ and Ronny Berndtsson ${ }^{1,4}$ \\ 1 Division of Water Resources Engineering, Lund University, Box 118, SE-221 00 Lund, Sweden; \\ rolf.larsson@tvrl.lth.se (R.L.); ronny.berndtsson@tvrl.lth.se (R.B.) \\ 2 Division of Risk Management and Societal Safety, Lund University, Box 118, SE-221 00 Lund, Sweden; \\ per.becker@risk.lth.se \\ 3 Unit for Environmental Sciences and Management, North-West University, Private Bag X6001, \\ Potchefstroom 2520, South Africa \\ 4 Centre for Middle Eastern Studies, Lund University, Box 201, SE-221 00 Lund, Sweden \\ * Correspondence: shifteh.mobini@tvrl.lth.se
}

Received: 11 August 2020; Accepted: 9 November 2020; Published: 11 November 2020

\begin{abstract}
Urban flooding is a growing concern in Northern Europe. While all countries in this region invest substantial resources into urban flood risk management, all property owners have unequal opportunity to have their flood risk managed. This paper presents the notion of equity in the urban flood risk management, focusing on urban flood exposure and compensation after sewage surcharge on the 31 August 2014 cloudburst over Malmö in Sweden. All damage claims and the procedures assessing them were analysed based on the type of sewer system (combined or separated) that affected the properties. The results demonstrated considerable systemic inequity in both flood exposure and damage compensation. The owners of properties connected to combined systems were four times more likely to make a damage claim, while having their damage claims approved just over half as often, compared with owners of properties connected to separated sewage systems. Considering the multifaceted nature of both inequities and their possible resolution, current praxis is not sufficient for the management of future urban drainage systems; not only concerning changing climatic conditions but also concerning social conditions.
\end{abstract}

Keywords: basement flood; damage claim; equity; flood risk management; sewer system

\section{Introduction}

Urban flooding from high-intensity rainfall is causing extensive and increasing damage to cities around the world [1]. This includes different types of floods in urban areas, such as fluvial, groundwater, coastal, pluvial, and sewer floods [2-4], out of which the two latter are of particular interest for this study as they stem from insufficient capacity in urban drainage systems [5-7]. There are many drivers behind escalating flood risk [8], out of which urban densification, population growth, and increasing impermeable surfaces have attracted particular attention [3,9]. The expected effects of global warming are also often considered [10], such as an increase in short high-intensity rainfalls, which in Sweden usually occur in summer [11]. Recent years have seen a series of damaging cloudbursts across Northern Europe [12,13], such as the 2011 cloudburst over Copenhagen resulting in over EUR 800 million in damage [14], and the 2014 cloudburst over Malmö resulting in a record number (more than 2000) of damage claims directed both to insurance companies and to the municipal water and wastewater utility [15]. Pluvial flooding in the Netherlands generates costs of about EUR 90 million per year, and the prediction is that this could increase to EUR 200 million per year [16]. Pluvial and sewer flooding entails not only an economic burden but also health-related impacts due to contact with 
contaminated water and mental stress issues [14,17]. Flooding is a complex interlinked phenomenon, affecting physical, economic, and social environments at different spatial and temporal scales [18]. This paper focuses explicitly on basement floods concerning insufficient capacity in the sewer drainage system, i.e., water entering a building after having amassed in the urban landscape due to precipitation overwhelming its natural and engineered drainage capacity [4]. The city of Malmö in Sweden has a historical record for pluvial and sewer flooding. The mechanisms behind three major flood events with a large number of damage claims, namely in 2007 (150 damage reports), 2010 (210 damage reports), and 2014 (2109 damage reports) were studied [19]. The 2014 flood event in Malmö is of particular interest because of the large number of damage reports [15] and the expected future increase in both the frequency and intensity of extreme rainfall over Sweden [20]. The cloudburst event on 31 August 2014 lasted $6 \mathrm{~h}$, and was captured by many rain gauges with a return period bigger than 100 years [15,19]. The highest observed rainfall for this event was $122 \mathrm{~mm}$. The return period for this rainfall was estimated as about twice of what had previously been considered a 100 year rainfall event $(69 \mathrm{~mm})$ making this event a historical record [15].

Modelling and designing urban drainage systems capable of managing high-intensity rainfall have attracted intense scientific attention [21,22]; however, such systems are to date not typically designed to accommodate cloudbursts [23]. This capacity is limited regardless of the expected effects of climate change, and will result in increased flooding in Sweden [24]. The design of urban drainage systems influences pluvial and sewer flooding significantly, and as well the spatial variation within a city [19]. The function and type of an urban drainage system (combined or separated) have a direct impact on the exposure element of the well known "risk triangle", which shows risk as a function of hazard, vulnerability, and exposure [25]. In the flooding context, the hazard is the probability of a flood event, the exposure is a measure of the population and buildings that would be affected, and vulnerability is the lack of capacity to withstand the event [26]. The flood risk assessment (hazard, exposure, and vulnerability) provides valuable inputs for flood risk management, in particular considering the social vulnerability of people to flood damage [27].

In this study, we do not carry out a flood risk assessment which is an important tool to provide input for the evaluation of flood risk management; instead, we examined the structural exposure to urban flooding and investigate if damage claims from property owners are being managed fairly. Justice, fairness and equity all have their implications with regard to fair treatment [28]. The concept of inequity is introduced in this work to raise a warning flag about the consequences of a specific system for damage compensation regarding fair and equitable flood risk management [29]. By equity, we mean that all citizens should be treated equally and have equal opportunity to have their flood risk managed [30]. This is particularly relevant regarding households within the same city, as issues of inequity in such a case cannot be explained by differences in legislation, climate, location, political colour, or management style. Inequity occurring within a city would thus be a strong indication of fundamental inequity resulting from the system of flood risk management in general. As well, we have included inequity as a consequence of systematic differences in flood exposure between the properties connected to combined versus separate sewer systems. We are not aware of any previous studies of this kind. The study is thus an innovative and important contribution to improve future flood management.

The purpose of this paper was thus to investigate the equity of the Swedish system for urban flood risk management, focusing on urban flood exposure and compensation after sewage surcharge for the 2014 cloudburst over Malmö. To meet this purpose, the paper intends to answer the following research question: to what extent are all citizens equally treated and have equal opportunity to have their flood risk managed in Malmö, Sweden? 


\section{Conceptual Framework}

\subsection{Urban Drainage Systems}

An urban drainage system handles two types of water in cities [31], stormwater and wastewater. These systems were historically designed to remove polluted sewage from the city due to health issues [32] and served to drain surface water after rainfall [33]. The systems for urban drainage in Europe before the 1960s were thus combined sewer systems using the same pipe for both wastewater and rainwater [34]. After the 1960s, cities in Sweden started to build separated sewage systems for wastewater and stormwater due to demands for both reducing the pressure on the treatment plants and reducing the amount of overflow of untreated wastewater to receiving waters [19]. The decisions of where to separate the systems were based on natural and technical reasons, under budget constraints. This change happened across Northern Europe, although the percentage of combined sewer systems in Sweden (13\%) is lower than in neighbouring Denmark (48\%) and Norway (31\%) [35].

The design criteria for the capacity of pipes are based on statistical return periods of observed intense rainfall [36], which are also used when investigating if the municipal water and wastewater utility has fulfilled the legal requirements in case of flooding [37]. Although, all combined systems in Sweden are currently expected to handle flows resulting from rainfalls with a 10 year return period, without causing basement flooding (ibid), there are still many areas that can only handle 2 to 5 year return period rainfall since the design criteria were based on 2 to 5 year rains at the time of construction [38]. The issue at hand is that the old pipes were designed correctly at the time of their construction, but now the requirements have changed. However, regardless of the expected capacity being 2 to 5 year or 10 year, none of these systems can handle an extreme cloudburst like the one that hit Malmö in 2014 [39,40].

The failure of the urban drainage system that resulted in extensive basement flooding in Malmö during the cloudburst event is inherent in the design capacity, which is not meant to handle the cloudburst event. The expected functional capacity from a combined sewer is 10 year rainfall and the cloudburst event was significantly larger than a 100 year rainfall. When the maximum capacity of the drainage system has been reached, flooding will occur. Where this occurs depends on the type of drainage system, with combined sewer systems entailing a more considerable problem of hydraulic surcharge through the lowest-lying sewer inlets, which are usually in basements [41]. However, property damage can also occur as a result of surface floods and flood water leaking into the property [19].

\subsection{Damage Claim Process}

The distinction between the types of flood damage-(1) flood damage due to surface flooding, (2) flood damage via the sewage system, and (3) flood damage as a result of leakage into the property-is central to the damage claim process in Sweden [19]. The water and wastewater utility, which has the municipal responsibility in Sweden, is only accountable if the floodwater causing the damage has entered from the sewer system [37]. In other words, to be reimbursed, there should be a clear connection between the damage and its infrastructure.

It is essential to point out that the Swedish damage claim process differs from that in the neighbouring countries. In Norway, a 5 year return period rainfall is the limit of responsibility for basement flood damage claims. In contrast, the water and wastewater utility is not responsible at all for basement flood damage in Denmark and Germany [35,42,43]. In these countries, it is up to the property owners and the insurance companies to safeguard against flood damage.

In Sweden, the owner of a flooded property will usually contact their insurance company as a first step to claim the damage loss. This is included in their home insurance, and there is no separate flood insurance [44]. The insurance companies cover the initial cost but can claim it back from the municipal water and wastewater utility referring to the legislation from Swedish Public Water Services Act (SFS 2006:412). This is called a regress claim. Property owners can also claim back the deductible 
part not received from their insurance companies. The property owner damage cost, which is below their deductible portion, can also be claimed directly from the municipal water and wastewater utility. The damage claim process demands credible evidence of how the water entered the basement to determine the liability of the municipal water and wastewater utility, which is difficult when nobody has been present to observe how the water entered the basement during the event. This paper focuses on issues of equity between property owners and is only investigating the urban flood exposure and compensation, and not the negotiations between the municipality and insurance companies.

\subsection{Equity and Inequity}

Equity is an essential concept of this study that has its roots in notions of justice, fairness in the allocation of resources, and the equality of conditions [45]. There are different philosophical traditions (e.g., utilitarianism, pluralism, egalitarianism, and libertarianism) that emphasise diverse foundations for justice (e.g., rights, needs, merits, and interests) [30]. However, Rawls's principle of justice is particularly useful for this study since it addresses issues of vulnerability and provides a framework for evaluating equity. Equity is here relational and comparative and focuses on the relative circumstances of people [46,47]; most often between different groups of people on a specific timescale [48]. In this case, the equity among property owners in Malmö is investigated in terms of flood exposure and the processing of their flood damage claims depending on the type of sewage system their properties are connected to.

Numerous hydrological factors determine whether a particular property is flooded or not for a specific rainfall event $[19,49,50]$. However, this study is not concerned with these factors. It is instead focusing on the equity of treatment of the resulting flood risk at a societal level, which can be defined as "the quality of being fair and impartial" [51]. This means that all property owners should be equally treated and have equal opportunity to have their flood risk managed by societal actors [30], regardless of the type of sewage system their properties happen to be connected to. Equity is the antonym of inequity, which can be defined as a "lack of fairness or justice" [51]. Although there might be multiple issues of equity regarding basement floods, this paper focuses on systemic inequity between property owners.

\section{Methodology}

Case study research has been chosen as our method for this study [52]. The cloudburst on 31 August 2014 over the city of Malmö in Sweden recorded an intensity corresponding to more than a 100 year return period. The cloudburst lasted $6 \mathrm{~h}$ and measured between 51 and $122 \mathrm{~mm}$ at different rain gauges in the city. Previous studies have investigated in detail the rainfall intensity and its relation to flood damage for this event $[15,19,53]$. It was a significant flood event generating the highest number of flood damage claims for a single occasion in Sweden ever.

Malmö is the third largest city in Sweden, known for its well functioning urban drainage systems and established practices for sewer flood damage claims [19]. The population of Malmö municipality was around 320,000 according to Swedish statistics in 2015 [54]. The topography of Malmö is flat with $35 \mathrm{~m}$ as a maximum elevation [53]. Malmö is located in the southwest of Sweden (Figure 1). About $30 \%$ of the buildings are connected to the combined sewer system and $70 \%$ to the separated sewage system. Sewer flood damage claims have been registered since the 1990s [19]. The leading cause of flood damages in Malmö is pluvial flooding (ibid). 


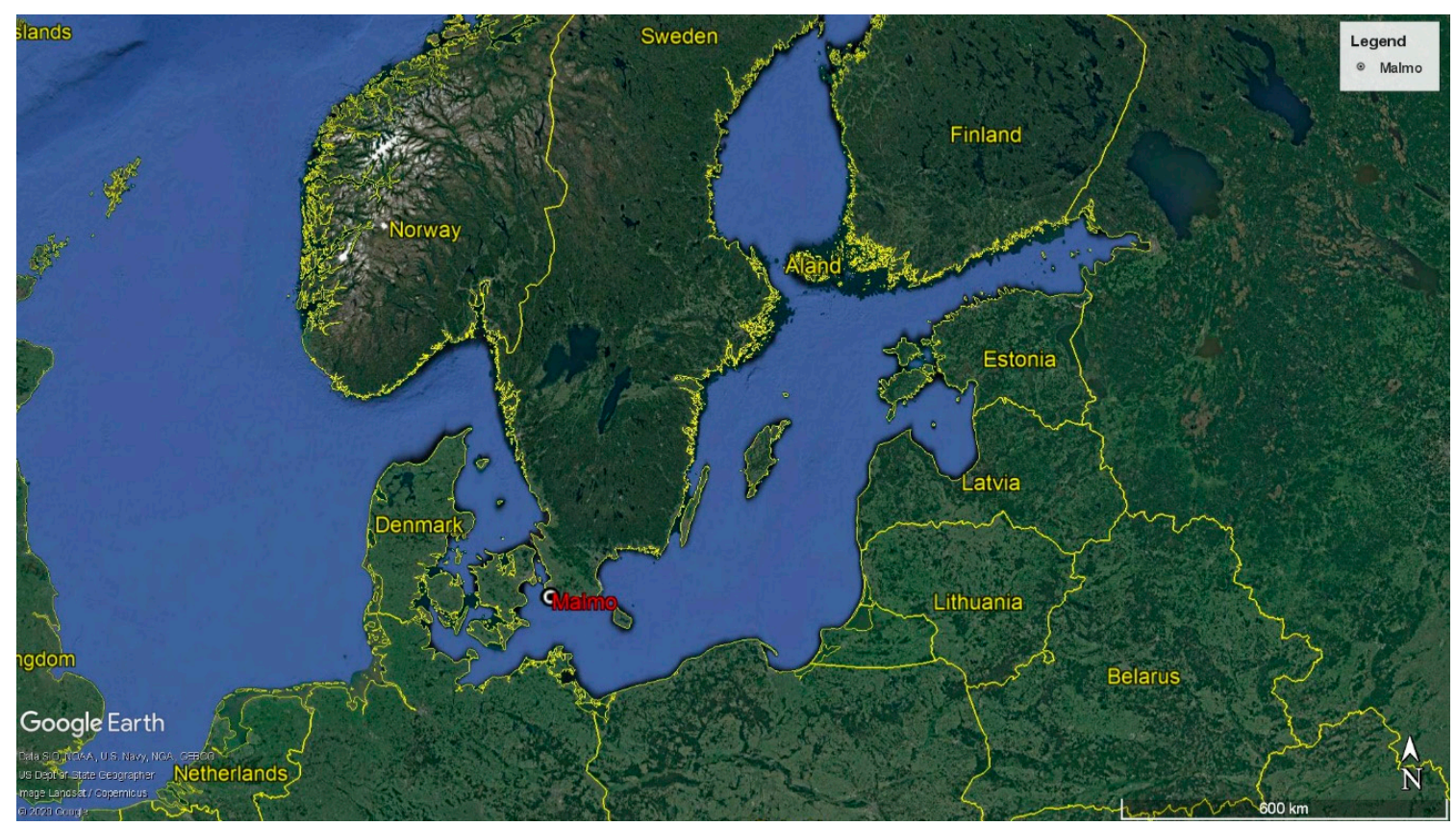

Figure 1. Map of Sweden and location of Malmö.

Flood damage claim data were collected from the municipal water and wastewater utility in Malmö. This register is based on damage claims that the municipal water and wastewater utility receives after floods, from property owners, insurance companies, and tenants. These claims are obtained via phone, an online registry, or by mail. The dataset has a significant variation in the description of the content, but all claims include the "date of damage", "location", "type of claim", and "decision". Due to the confidentiality of the decision for an insurance company, we did not receive any final decisions for that category. Other necessary data were the "type of sewer system" that the property was connected to, and the reason for flood damage (Table 1).

Table 1. Example of data for the damage claims.

\begin{tabular}{ccccc}
\hline Date of Damage & $\begin{array}{c}\text { Type of Sewer } \\
\text { System }\end{array}$ & $\begin{array}{c}\text { Reason for Flood } \\
\text { Damage }\end{array}$ & Type of Claim & Decision \\
\hline 31 August 2014 & $\begin{array}{c}\text { Combined } \\
\text { or } \\
\text { separated }\end{array}$ & $\begin{array}{c}\text { Rainfall-related via } \\
\text { the sewer system }\end{array}$ & $\begin{array}{c}\text { Property owner } \\
\text { Approved } \\
\text { or } \\
\text { rejected }\end{array}$ \\
\hline
\end{tabular}

Everyone can claim their damage from the municipal water and wastewater utility in Sweden. The dataset was therefore assumed to be representative for the flood event. It is also important to note that no active sampling was conducted, which means that the dataset comprised the entire population of damage claims.

The data were analysed by first sorting flood damages caused by rainfall-related flood damage (sewer flooding). Although the "reason for flood damage" is not always included in the damage claim register, it was assumed that the claims made concerning floods on 31 August 2014 cloudburst were all related to rainfall which has also been verified and studied before $[15,19]$. Snowmelt was not involved in this event since it occurred in the summer. Each damage claim was then checked against urban drainage systems maps, to identify the damages related to the combined and separated sewer system, respectively. The decisions were studied in detail to identify potential issues of inequity.

Pearson's $\chi^{2}$ (chi-square) statistical test was applied to test for the statistical significance of any observed patterns in the results between properties connected to combined- or separated sewer systems, or if these patterns could be explained by chance [55-57]. Pearson's $\chi^{2}$ is commonly used as a test of 
association between variables in a bivariate table, or crosstabulation, and provides an opportunity to examine whether the observed counts are significantly different. This analysis was carried out with the assistance of the statistics software SPSS.

Data were also collected through participant observation of the procedure of claim handling at the municipal water and sewage organisation during 16 months immediately after the cloudburst. The observations were done by one embedded researcher working full time with the handling of the claims, in the team of the professional staff of the municipal water and wastewater utility. As Woodside [58] described, participant observation has proven useful in organisational settings, as it provides opportunities to observe directly how the organisation makes sense of the situation, frames the problem, plans and performs its activities, and evaluates the outcomes.

\section{Results}

\subsection{Distribution of Damage Claims and Exposure}

There were 1959 damage claims in the database that could be analysed, including claims from insurance companies, private property owners, and tenants. There were 1257 claims from properties that were connected to the combined sewer system (one pipeline for both stormwater and wastewater) and 702 from properties that are connected to the separated sewer system (two pipelines, one for only wastewater and one for stormwater). The distribution of claims is thus skewed between the two types of urban drainage systems, with $64 \%$ of the claims from properties connected to the combined sewage system and 36\% from properties connected to the separated sewage system (Table 2). This is particularly interesting, considering that only 30\% of the properties in Malmö are connected to the combined sewage system. This means that properties connected to this type of sewage system were four times more likely to make a damage claim for the 31 August 2014 cloudburst as compared to properties connected to the separated sewage system (Figure 2).

Table 2. Overview of the distribution of sewage types and claims for 31 August 2014 cloudburst in Malmö.

\begin{tabular}{cccc}
\hline Sewage Type & Proportion of Connected Properties & Number of Claims & Proportion of Claims \\
\hline Combined system & $30 \%$ & 1257 & $64 \%$ \\
Separated system & $70 \%$ & 702 & $36 \%$ \\
Total & $100 \%$ & 1959 & $100 \%$ \\
\hline
\end{tabular}

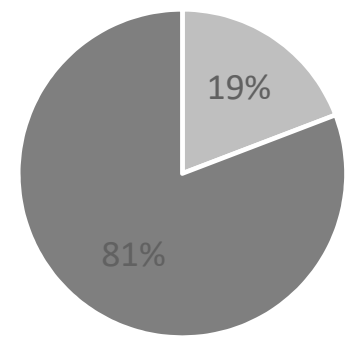

\section{- Separate system - Combined system}

Figure 2. Distribution of exposure to damage in terms of claims from different sewage system types.

\subsection{Distribution of Damage Claims from Property Owners and the Rate of Approval}

The damage claims are generally distributed between two main categories of claimants: (1) Insurance companies making regress claims to be reimbursed for pay-outs to their insurance holders, and (2) property owners making claims to be reimbursed for their insurance excess or directly claiming the damage cost (Table 3). There is also a limited number of claims from tenants. However, these are automatically discarded since there is no direct legal contract between them and the municipal 
water and wastewater utility. About two-thirds of the claims came from insurance companies, which always claim back their costs, and about two-thirds of these claims concerned properties connected to the combined system (Table 3). We did not receive the results of compensation decisions for the insurance companies due to confidentiality issues. However, as our aim is the application of the notion of equity in how damage claims are being handled for individuals living in the city, the claims from the insurance company are of limited interest for this paper. They are only used as a reference point concerning the proportion of property owners claiming back their insurance excess.

Table 3. Distribution of damage claims depending on the type of claimant.

\begin{tabular}{cccc}
\hline Sewage Type & Insurance Company & Property Owner & Tenants \\
\hline Combined system & 887 & 356 & 14 \\
Separated system & 448 & 219 & 35 \\
Total & 1335 & 575 & 49 \\
\hline
\end{tabular}

We investigated the distribution of claims within the group of property owners. Among these damage claims, 97 (combined system) and 99 (separated system) did not have a matching claim from the insurance company. The procedure for the damage claim is that the property owners start by claiming the damage cost from their insurance company and then they can claim their deductible from the municipal water and wastewater utility. This will be described in more the detail in Section 4.3. Therefore, in total, there were 379 property owners who claimed their deductible cost and 196 who claimed their total cost.

One likely reason why only 379 property owners claimed their deductible out of 1335 damage claims is unawareness among property owners regarding their right to also claim their deductible from the municipal water and wastewater utility. Logically, there should have been an equal number of damage claims for each category as a claim from an insurance company means that the insurance company already investigated the damage with the property owner and property owners did pay the deductible part to them.

Since the focus of this paper was to explore potential issues of inequity among citizens, it was important to investigate the rate of approval of damage claims from property owners. The spatial distribution of these damage claims indicates substantial similarity in the location of the damaged properties connected to combined and separated sewer systems (Figure 3). However, when analysing the 575 damage claims in detail, striking differences were found between the properties connected to the two different types of sewage system (Table 4).
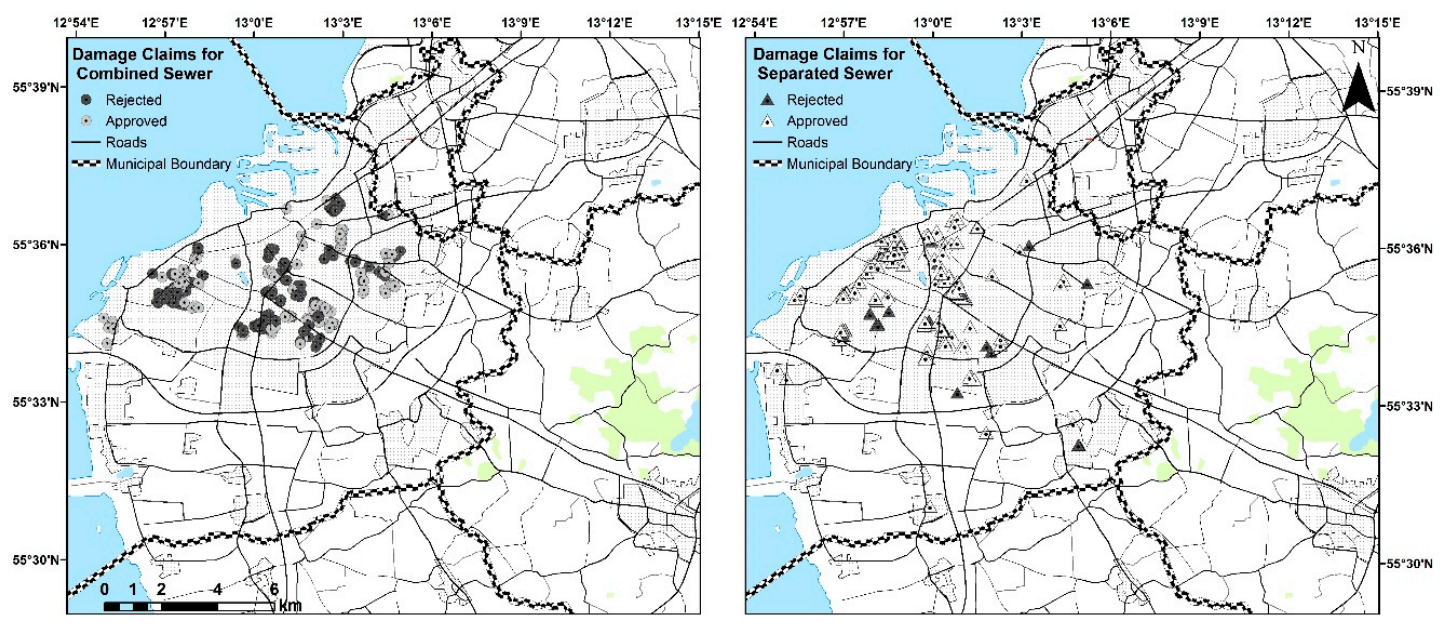

Figure 3. Spatial distribution of damage claims for property owners per type of sewer system (combined on the left side and separated on the right side) and decision on compensation for the 2014 cloudburst in Malmö. 
Table 4. Property owner damage claim compensation from the municipal water and wastewater utility.

\begin{tabular}{ccccc}
\hline Sewage Type & $\begin{array}{c}\text { Number of Claims from } \\
\text { Property Owners }\end{array}$ & $\begin{array}{c}\text { Number of Claims } \\
\text { Approved }\end{array}$ & $\begin{array}{c}\text { Number of Claims } \\
\text { Rejected }\end{array}$ & $\begin{array}{c}\text { Number of Claims } \\
\text { with no Decision }\end{array}$ \\
\hline Combined system & 356 & 165 & 184 & 7 \\
Separated system & 219 & 177 & 29 & 13 \\
Total & 575 & 342 & 213 & 20 \\
\hline
\end{tabular}

Out of the 349 damage claims from properties connected to a combined sewer system that had been settled to date, 184 did not receive compensation (Table 4). This means that only $47 \%$ of these claims received compensation (Figure 4). The reason for rejection or approval is going to be discussed in the next section (Section 4.3). On the other hand, when looking at the 206 claims from the owners of properties connected to the separated system with a decision, only 29 claims were rejected (Table 4). This means that $86 \%$ of these claims received compensation (Figure 4). This corresponds to an $83 \%$ higher approval rate than for properties connected to a combined system. Using Pearson's $\chi^{2}$ to analyse this pattern of approved and rejected damage claims for the properties connected to combined and separated sewer systems (crosstabulation in the centre of Table 4) demonstrates statistical significance (Pearson's $\chi^{2}=81.8, p<0.001$ ).
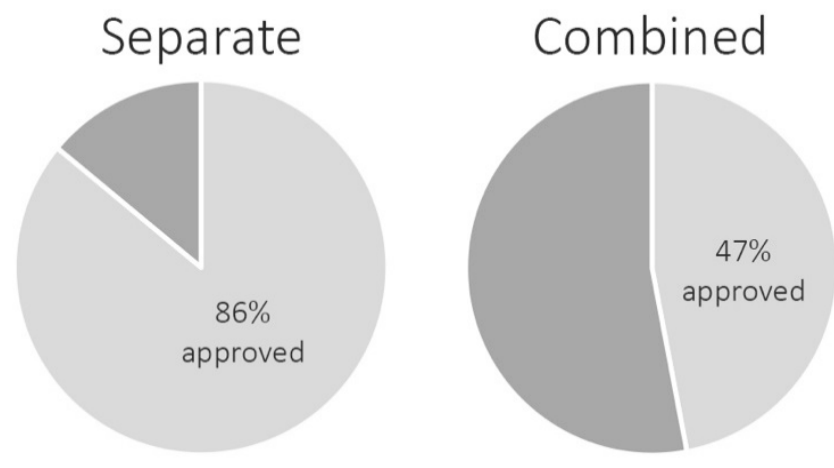

Figure 4. The claim approval rate for properties connected to different types of sewer system.

\subsection{Observed Damage Claim Procedure}

Damage claims to the municipal water and wastewater utility must be investigated according to the Swedish Public Water Services Act (SFS 2006:412, §44-46). Everyone can make a damage claim, but the procedure for approval is different for each category of claimants, i.e., insurance company, property owner, and tenant. There are two distinct procedures for assessing responsibility after basement flooding, based on the type of sewer system. During the observation period, there were daily telephone calls from people wanting to make a claim. It was clear from these conversations that property owners are not aware of what type of sewer system their property is connected to. The professionals handling the claims at the municipal water and wastewater utility check the type of sewer connection from existing technical maps and file the claim to be processed as either connected to a combined or a separated system. The simplified flow chart for the damage claim procedure is shown in Figure 5. This is further described in Sections 4.3.1 and 4.3.2. 


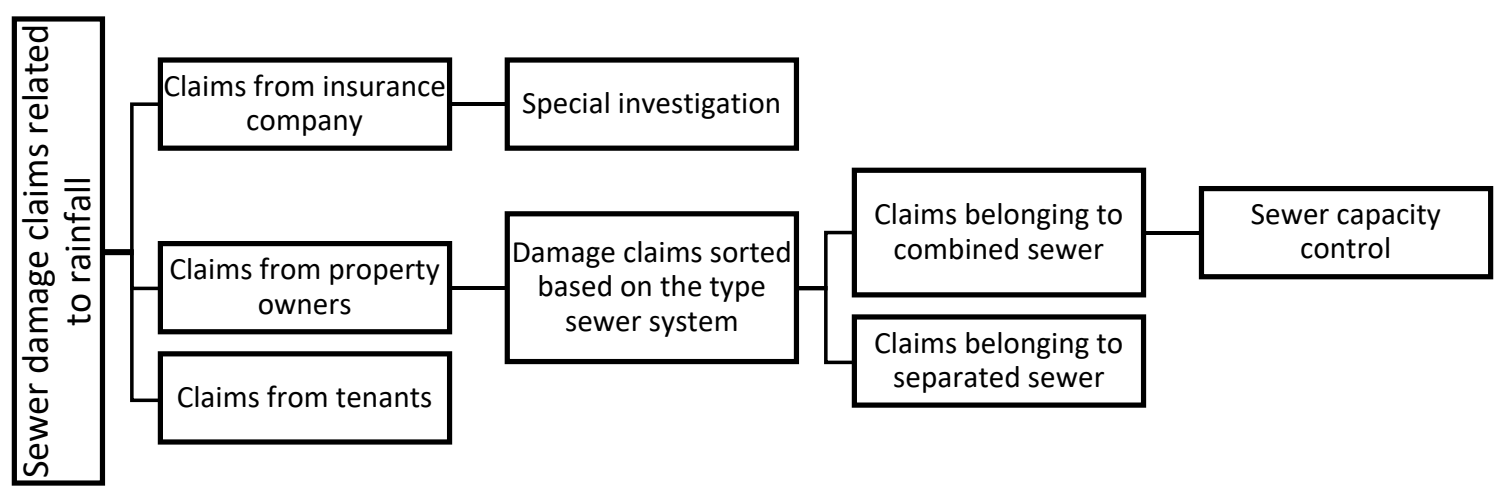

Figure 5. Simplified flow chart of the damage claim procedure.

\subsubsection{Procedure for the Combined Sewer System}

The damage claims concerning properties connected to a combined sewer system undergo a specific investigation procedure, based on advanced engineering practices to ensure the expected capacity of the sewer pipeline. The regulations state that the municipal water and wastewater utility is responsible for such systems to cope with rainfall no more intense than statistically recurring in 10 years [37]. The 10 year rainfall is, in other words, the limit of responsibility. The municipal water and wastewater utility must thus investigate the actual capacity of the combined sewer system with reference to the basement level of each property making a claim. If the investigation finds that a property is connected to a combined system, which meets the legally required capacity demand-handling the 10 year rain - the municipal water and wastewater utility fulfils its legal responsibility, and the damage claim is rejected regardless of the intensity of the rainfall event. If the investigation instead finds that the combined system does not meet the legal requirement, the municipal water and wastewater utility is responsible for the basement flood and must approve the damage claim.

Investigating the capacity of the combined sewer system, which is shown in Figure 5, with reference to the basement level of each property, is done using hydraulic models. These hydraulic models are advanced established tools that require technical competence and crucial input data, such as the catchment area, sewer system, surface characteristic and the rainfall data. The main input to the hydraulic drainage modelling is rainfall data. Rainfall data are time series either in the form of accumulated rainfall depths or average rainfall intensities. A common procedure for capacity control is to use synthetic rainfall, such as block rainfall with constant intensity over its duration [59]. There is a long history of research in the estimation of uncertainty of rainfall data [39,60,61]. Using different rainfall data as input to the urban drainage models will result in different location of the surcharge and flooded basements. Furthermore, different results will be attained using different types of rainfall time series as input (e.g., single event, synthetic rainfall, observed rainfall, design rainfall) [60]. Studies have shown that there are also reports with the indication of possible systematic errors of up to $30 \%$ with the use of tipping bucket gauges, which is a dominating method for observing rainfall [62].

The European standard EN752 (2017) recommends the use of "design storm frequency" for the design of sewage systems. This means that maximum flow capacity and surcharge are related to the return period of the design storm. In other words, there is an assumption of steady flow and linear relationship between rainfall intensity and design flow at a specific point in the system. However, the evaluation of the sewage system and what is asked for according to national guidelines is the return period of urban flooding and not the return period of the rainfall. Due to the complexity of urban sewage systems in big cities with a multitude of hydraulic structures, e.g., weirs, gates, retention basins, etc., estimating the return period of flooding at a specific point based on the return period of the rain is very difficult $[39,63]$. There is a complex relationship between rainfall intensity and flooding response, which makes the return period of rainfall not automatically equal to the return period of flooding which is assumed in the existing design criteria $[39,60]$. 
Moreover, the basement level might be available from existing installation drawings for each property or must be assumed in relation to a known reference point. In any case, the result of the hydraulic model is a hydraulic grade line, showing if the basement of the property would be flooded by a 10 year rainfall or not (Figure 6). This means that two hypothetical houses along the same street and connected to the same combined sewer system may have different outcomes in relation to their damage claims in relation to the same cloudburst, regardless of the actual rainfall intensity. This is because the hydraulic model may indicate that the combined system has sufficient capacity, in relation to the 10 year rainfall, to keep floodwater out of the basement of one house (house B), which means that the claim from its property owner is rejected, while the system has insufficient capacity to keep water out of the basement of the other house (house A), which means that the claim from its property owner is approved (Figure 6).

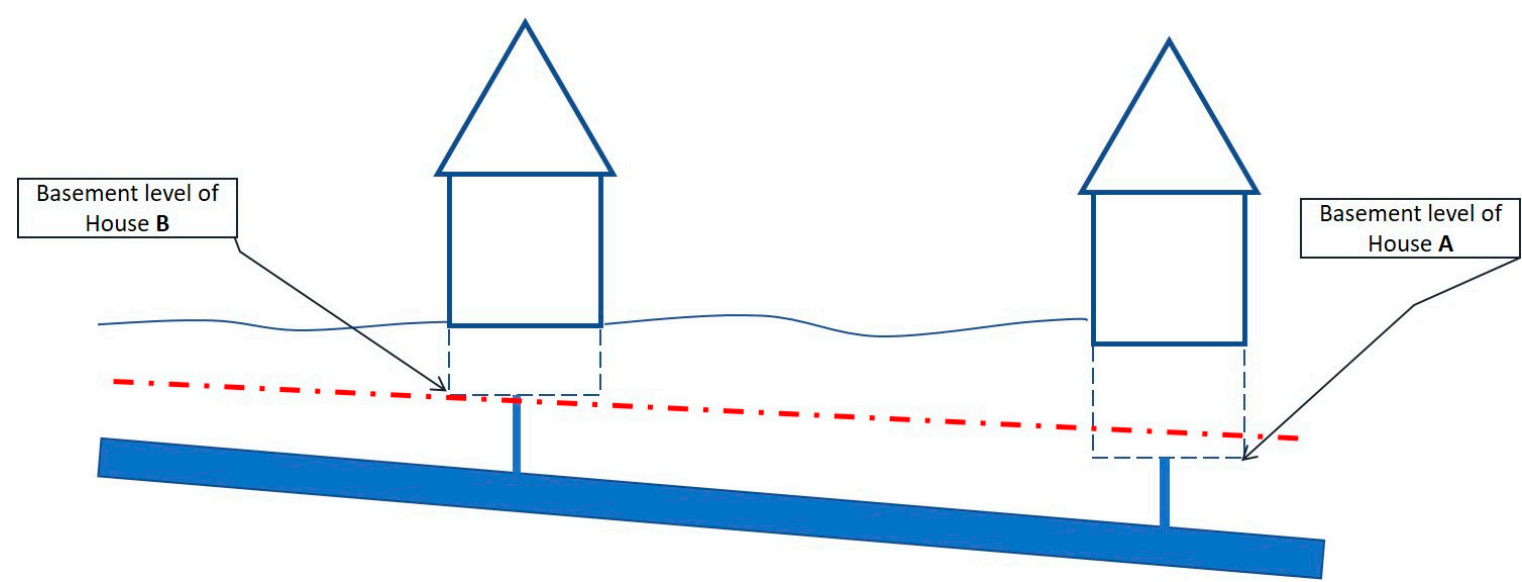

Figure 6. Basement levels in relation to the capacity of a combined sewer pipe during a 10 year return period rainfall event. The profile shows a hypothetical case with houses A and B that are connected to a combined sewer pipe with a hydraulic grade line (dotted line) resulting from an urban drainage model with a 10 year return period rainfall input.

\subsubsection{Procedure for the Separated Sewer System}

The damage claims concerning properties connected to a separated system (the house is connected to two pipelines, one for stormwater and one for wastewater) has an entirely different procedure based on a description of how flooding occurred in each claim. The legal practice is straightforward for damage claims for properties connected to separated sewer systems; a separated sewer system must never cause basement flood damage regardless of rainfall intensity, since there is a separated pipeline for draining the stormwater. This makes the municipal water and wastewater utility automatically responsible in the case of basement flood via the sewer system, which evidently can happen in intense rainfall due to leakage and intrusion of surface runoff. Hence, the critical part of this procedure is to establish how the flood water enters the property during the rainfall. If the flood water enters via the sewer system - e.g., through a floor drain—it is the responsibility of the municipal water and wastewater utility. However, if the floodwater enters the property via leakage of surface water-e.g., through ventilation, doors and windows, garage entrance, etc.- - then the municipal water and wastewater utility is not responsible. Since only the property owner, at best, observed the basement flood, the damage claim procedure is mainly based on assessing the phrasing of the event in the damage claim. Therefore, all damage claims from property owners describing that the floodwater entered via floor drains, and not from any leakage of surface water, in principle become approved. 


\section{Discussion}

\subsection{Systemic Inequity of Flood Exposure}

The results demonstrate clear inequity in exposure to basement floods among properties connected to combined sewage systems in Malmö. Property owners connected to a combined system were four times more likely to make a damage claim for the 31 August 2014 cloudburst than owners of properties connected to the separated sewage system. The fact that combined systems pose a higher risk of a basement flooding is firmly established by previous research [15,32,64]. Reports from Malmö for three flood events in 2007, 2010, and 2014 showed that properties connected to the combined sewer system are more exposed [19]. However, for equity to be meaningful, it must be quantified [65]. Moreover, Reckien et al. [66] pointed out three different dimensions of equity concerns to be considered-(1) outcome-based, (2) process-oriented, and (3) contextual—out of which the first two are focused on here.

There are apparent hydraulic reasons behind the outcome-based inequity in flood exposure between properties connected to combined- or separated sewer systems, as a consequence of policy and action over time [66]. The combined sewer systems were designed for 2 to 5 year return period rainfall which was correct according to the regulations at the time of design. However, with present regulations, they must be able to cope with 10 year return period rainfalls without causing basement flooding. One could argue that if properties had backwater valves on their sewer laterals that this would affect the level of flood exposure [67]. Accordingly, there are recommendations and campaigns to encourage property owners to install backwater valves and handle rainwater locally. However, neither insurance companies nor municipal water and wastewater utilities in Sweden require property owners to install backwater valves. Another contributing factor in increasing the risk of flooding is the age and condition of the sewer system. Normally, combined sewer systems are older than the separated systems. This could imply more risk for reduced capacity of the pipes. On the other hand, there are good examples of very old pipes that due to their shape, e.g., egg-shape section and material construction, have a better function than newer pipes [68].

The hydrological/technical explanations for variation in flood exposure described above do not change the fact that the property owners in the city are systematically exposed to different exposure and risk in the city depending on whether they are connected to combined or separate sewer systems. This difference needs to be highlighted and discussed in a transparent manner. However, our focus is not on the physical and technical explanations of variation in flood exposure. Instead, we want to point out how it is distributed in a systematically different way within one city and how this affects house owners. Even if properties connected to separated systems may be flooded through overflow and surcharge during particularly intense rainfall-as during the studied cloudburst-properties connected to combined systems are dramatically more likely to be flooded. This means that if all sewer systems remained combined, as in the past, there would be no inequity in flood exposure, but many more flooded properties; provided that property owners do not mitigate the problem independently. However, if one property owner mitigates flood risk by installing a check valve to prevent water from flowing backwards into the property, it may inadvertently increase flood risk for neighbouring properties. There would also be no inequity if all sewer systems were separated, but that is neither economically nor technically feasible. It is important to note that the separated sewer systems in Malmö were not designed only to reduce flood risk, which also could have been addressed through the installation of local check valves on every property along with a combined system; acknowledging that the water would then end up somewhere else. It was also done for environmental reasons to reduce the pressure on sewage treatment plants [19]. It was as such a well motivated investment, even if it again demonstrates that engineering is better at addressing economic and environmental issues than social issues [69].

In relation to more process-oriented concerns of inequity, it is essential to consider the funding arrangements for municipal water and wastewater utilities in Sweden and most other E.U. countries. Here, the infrastructure and services are financed by a fee paid into a collective by all property owners 
connected to a sewage system, which is the same regardless of the type of system the property is connected to [70]. This means that all property owners contribute equally to these infrastructures and services, while the processes utilising the funding-processes outside their control—result in some of them ending up more exposed to basement flooding than others. It is also crucial to consider the lack of awareness of property owners concerning the type of sewer system their property is connected to, and of the flood exposure that entails. Such lack of awareness has been identified in other countries as well [71]. If it would have been a conscious choice to buy a high-risk property in relation to a basement flood, this aspect of inequity would be less problematic; provided the buyer could afford and had a choice to buy another property. Now it is simply a matter of brute luck for the vast majority of property owners, which is a central concern for both understanding and addressing inequity [72].

Moreover, the awareness of sewer type and associated flood risk is important to motivate activities to reduce flood risk among property owners. For instance, van Ootegem et al. [5] showed that being aware of flood risk before a basement flood reduces the material damage by $90 \%$ on average. Promoting equity thus entails timely and equal access to information for all present and prospective property owners, which is challenging as people tend to forget risks associated with infrequent events [73].

The last dimension of equity involves context; linking the outcome and process-oriented dimensions with the consideration of political, economic, and social conditions [66]. While this dimension is both interesting and important in order to grasp inequity in flood exposure, it is not the main focus of this paper and requires additional data regarding each property owner. What can be stated, though, is that the owners of properties connected to combined systems are generally worse off concerning basement floods and that equity concerns demand improving the position of the least advantaged [74].

\subsection{Systemic Inequity of Damage Compensation}

In addition to the inequity in flood exposure, the results also demonstrate systemic inequity in both the outcome and process of the damage claims from property owners. Owners of properties connected to combined systems were not only four times more exposed to basement floods in the studied cloudburst in Malmö, but have had their damage claims approved just over half as often as the owners of properties connected to separated systems. This conspicuous discrepancy in the outcome of submitted damage claims must again be considered in relation to the funding arrangements for municipal water and wastewater utilities since it is the same collective money that must also be used to assess and reimburse damage claims. This means that all property owners contribute equally to the available funding, while the owners of properties connected to separated systems have much better chances of accessing it to cover potential flood damages.

This apparent inequity in outcome is tightly connected to inequity in the legally stipulated processes for assessing the damage claims from owners of properties connected to separate or combined sewer systems. While the assessment of damage claims from the former is essentially based on the phrasing of the owners' narratives of the flood event, damage claims from the latter are assessed in relation to a technocratic examination of the capacity of the system in relation to the 10 year rainfall. There are several fundamental issues of inequity here. First of all, there is a distinct difference in the involvement of property owners, with owners of properties connected to separated systems being allowed to influence the assessment process while the owners of properties connected to combined systems are decoupled from it. This distinction is important as it has been pointed out that having no control over the situation plays a key role in ideas of fair compensation [75]. Secondly, there is a fundamental difference in legal responsibility, where the municipal water and wastewater utilities bear full responsibility for any water entering a property through a separated sewer system-regardless of rainfall intensity-but is only responsible for water entering through a combined system that does not have the capacity to handle the stipulated 10 year rainfall. However, there are many combined sewer systems designed only to handle earlier legal requirements of 2 to 5 year return period rainfall [38], this difference of the water and wastewater utilities bearing the full or only partial responsibility is 
crucial for discerning inequity in this context. Finally, there is inequity in the amount and type of uncertainty involved in the two different assessment processes. Aside of the intrinsic uncertainty in how water actually entered the property, over which the property owners have the explanatory prerogative, there is relatively little uncertainty in the assessment process for damage claims related to separated systems. However, uncertainty is inherent in any attempt to understand and address urban floods [76] and spills over more fundamentally into the process of assessing damage claims related to combined systems. This is because it entails hydraulic models that-even after decades of research into their uncertainties [77,78] —entail several sources of uncertainty; e.g., model parameters, input data, calibration data, and model structure [62,78-80]. Regardless of the uncertainty in the result, which is exacerbated by most practitioners using the default model settings irrespective of circumstances [77], it is the officially stipulated input determining if a claim is approved or not.

It is interesting to note the marked difference concerning damage claims to the water and wastewater utilities without making an insurance claim, which comprises almost half the claims related to separated systems and only about a quarter of the claims related to combined systems. This could indicate a larger portion of substantial damage in the latter properties but requires additional data to investigate in empirical terms.

\section{Concluding Remarks}

The analysis of the inequities in flood exposure and damage compensation suggest compounded inequity in urban flood risk that demands serious attention. It is brute luck that determines on which side of the divide between advantaged and disadvantaged most, if not all, property owners end up. Following Dworkin's [72] influential ideas of justice, it is particularly important to attempt to address such inequities, which are entirely beyond the control and choice of the property owners. Property owners do usually neither know what type of sewer system their property is connected to nor the implication on flood exposure. Even if becoming aware of the crucial importance of the sewer type, this has no influence over decisions concerning separating the pipes for wastewater and rainwater for their property. Such decisions are made by the municipal water and wastewater utilities predominantly based on technical and environmental factors. However, by informing people about the flood-prone areas in town, the property owner will at least have a chance to minimise the damage, like removing valuables from the basement and have different interiors in their basements. Furthermore, flood risk is not static, but changing; not only due to climate change [81] but also as a result of alterations in the sewer systems that most property owners are unaware of. When their property is flooded, they have their damage claim processed in fundamentally different ways, with one group having much better chances of approval than the other.

However, the inequity in flood exposure can be considered, what Alford and Head [82] call a very wicked problem; where neither problem nor solution is clear, and multiple parties with conflicting interests are involved. Hence, this is extremely difficult to address even for water professionals at water and wastewater utilities. Addressing this inequity in flood exposure would require large scale investments, similar to the governmental support for separating combined sewer systems in the mid-20th century. Since such support is highly unlikely, it is worth noting that the water and sewage utility in Malmö is currently running a successful project targeting property owners with information and incentives to contribute to reducing surface runoff during cloudbursts. Necessity is truly the mother of innovation.

On the other hand, the identified inequity in damage compensation can still be considered a complex problem. However, it is manageable by involving multiple parties each with complementing knowledge for arriving at a proper solution [82]. There are various options to improve this complex situation like for example by having a procedure for damage claims after a cloudburst event regardless of the type of sewer. Another solution could be to have differentiated monthly fees based on the type of sewers. House owners who are more exposed to flooding (combined sewer) pay less than owners who live in a safer area (separated sewer). This systemic inequity, while impossible for a water and 
wastewater utility to address itself since it must simply work in accordance with the legally stipulated system, can be addressed by further developing the legal framework and the associated tools for making new required assessments.

Considering the multifaceted nature of both the identified inequities and their possible resolution, it is time to challenge the disciplinary barriers that Harvey et al. [83] call the "art of being undisciplined", and to integrate technical, environmental, economic, political, and social knowledge in this endeavour. It is time to understand that current praxis is not sufficient for the management of future urban drainage systems; not only in relation to changing climatic conditions [84-86] but also in relation to economic and social factors. Any changes in infrastructure or services, or in the legal framework and stipulated practices, must thus be accompanied by assessments of their social impacts; to identify and address potential inequity in flood risk management.

In this study, we were unable to validate data with other registers (like the insurance companies or surveys of property owners) as the claims were anonymous. It is important to acknowledge and be aware that there could be human errors and uncertainty in our data source that could impact our findings. There is also a small risk regarding missing claims from insurance companies toward municipal water and wastewater utility, as they already compensated their customers (property owners) and therefore they will claim that cost. On the other hand, there could be more flood damage that was not reported and claimed from property owners toward the municipal water and wastewater utility due to unawareness of their right to claim. All in all, the uncertainties, which may affect the quantitative result results to a small degree, do not change the conclusions of this study.

This paper is a first step towards examining inequity, both in the exposure to floods and in the damage compensation. It focuses on outcome-based and process-oriented dimensions of inequity, and highlights the importance of further research into the contextual dimension of inequity; quantifying potential inequity in amounts of flood damage, and investigating patterns in who, in socioeconomic terms, face the greatest damage in absolute and relative terms.

Author Contributions: Conceptualisation, S.M. and P.B.; formal analysis, S.M. and P.B.; funding acquisition, R.L. and R.B.; investigation, S.M.; methodology, S.M. and P.B.; project administration, S.M.; resources, S.M.; supervision, R.L., and R.B.; visualization, S.M. and P.B.; writing-original draft, S.M.; writing-review and editing, S.M., P.B., R.L., and R.B. All authors have read and agreed to the published version of the manuscript.

Funding: This study was supported by a grant from Formas (The Swedish Research Council for Environment, Agricultural Sciences and Spatial Planning), No. 942-2015-149 (Sustainable Urban Flood Management).

Acknowledgments: The authors would like to acknowledge the personnel at VA SYD, the municipal water and wastewater utility in Malmö, for their support and flood damage claim data. Special thanks to Viveka Lidström for her support and great discussions as part of the mentorship program at the Water Research School. Finally, we would like to thank the Swedish Research Council Formas under contract 942-2015-149, and Sweden Water Research for financial support during this research.

Conflicts of Interest: The authors declare no conflict of interest. The funders had no role in the design of the study; in the collection, analyses, or interpretation of data; in the writing of the manuscript, or in the decision to publish the results.

\section{References}

1. Houston, D.; Werritty, A.; Bassett, D.; Geddes, A.; Hoolachan, A.; McMillan, M. Pluvial (Rain-Related) Flooding in Urban Areas: The Invisible Hazard; Joseph Rowntree Foundation: York, UK, 2011.

2. Nicklin, H.; Leicher, A.M.; Dieperink, C.; Van Leeuwen, K. Understanding the costs of inaction-An assessment of pluvial flood damages in two European cities. Water 2019, 11, 801. [CrossRef]

3. Hammond, M.J.; Chen, A.S.; Djordjević, S.; Butler, D.; Mark, O. Urban flood impact assessment: A state-of-the-art review. Urban Water J. 2015, 12, 14-29. [CrossRef]

4. Leal, M.; Ramos, C. The potential of two types of urban flooding to cause material damages in Lisbon, Portugal. Int. J. Saf. Secur. Eng. 2017, 7, 190-200. [CrossRef]

5. Van Ootegem, L.; Verhofstadt, E.; Van Herck, K.; Creten, T. Multivariate pluvial flood damage models. Environ. Impact Assess. Rev. 2015, 54, 91-100. [CrossRef] 
6. Bouwer, L.M. Projections of Future Extreme Weather Losses Under Changes in Climate and Exposure. Risk Anal. 2013, 33, 915-930. [CrossRef]

7. Bhattarai, R.; Yoshimura, K.; Seto, S.; Nakamura, S.; Oki, T. Statistical model for economic damage from pluvial floods in Japan using rainfall data and socioeconomic parameters. Nat. Hazards Earth Syst. Sci. 2016, 16, 1063-1077. [CrossRef]

8. Berndtsson, R.; Becker, P.; Persson, A.; Aspegren, H.; Haghighatafshar, S.; Jönsson, K.; Larsson, R.; Mobini, S.; Mottaghi, M.; Nilsson, J.; et al. Drivers of changing urban flood risk: A framework for action. J. Environ. Manag. 2019, 240, 47-56. [CrossRef]

9. Fratini, C.F.; Geldof, G.D.; Kluck, J.; Mikkelsen, P.S. Three Points Approach (3PA) for urban flood risk management: A tool to support climate change adaptation through transdisciplinarity and multifunctionality. Urban Water J. 2012, 9, 317-331. [CrossRef]

10. Glaas, E.; Neset, T.S.; Kjellström, E.; Almås, A.J. Increasing house owners adaptive capacity: Compliance between climate change risks and adaptation guidelines in Scandinavia. Urban Clim. 2015, 14, 41-51. [CrossRef]

11. Nie, L.; Lindholm, O.; Lindholm, G.; Syversen, E. Impacts of climate change on urban drainage systems-a case study in Fredrikstad, Norway. Urban Water J. 2009, 6, 323-332. [CrossRef]

12. Coulthard, T.J.; Frostick, L.E. The Hull floods of 2007: Implications for the governance and management of urban drainage systems. J. Flood Risk Manag. 2010, 3, 223-231. [CrossRef]

13. Rözer, V.; Müller, M.; Bubeck, P.; Kienzler, S.; Thieken, A.; Pech, I.; Schröter, K.; Buchholz, O.; Kreibich, H. Coping with pluvial floods by private households. Water 2016, 8, 304.

14. Zhou, Q.; Panduro, T.E.; Thorsen, B.J.; Arnbjerg-Nielsen, K. Verification of flood damage modelling using insurance data. Water Sci. Technol. 2013, 68, 425-432. [CrossRef]

15. Hernebring, C.; Milotti, S.; Kronborg, S.S.; Wolf, T.; Mårtensson, E. Skyfallet i sydvästra Skåne 2014-08-31: Fokuserat mot konsekvenser och relation till regnstatistik i Malmö. VATTEN J. Water Manag. Res. 2015, 71, 85-99.

16. Forrest, S.A.; Trell, E.-M.; Woltjer, J. Emerging citizen contributions, roles and interactions with public authorities in Dutch pluvial flood risk management. Int. J. Water Resour. Dev. 2020. [CrossRef]

17. Fewtrell, L.; Kay, D. An attempt to quantify the health impacts of flooding in the UK using an urban case study. Public Health 2008, 122, 446-451. [CrossRef]

18. Bernet, D.B.; Prasuhn, V.; Weingartner, R. Surface water floods in Switzerland: What insurance claim records tell us about the damage in space and time. Nat. Hazards Earth Syst. Sci. 2017, 17, 1659-1682. [CrossRef]

19. Sörensen, J.; Mobini, S. Pluvial, urban flood mechanisms and characteristics-Assessment based on insurance claims. J. Hydrol. 2017, 555, 51-67. [CrossRef]

20. Olsson, J.; Foster, K. Short-term precipitation extremes in regional climate simulations for Sweden. Hydrol. Res. 2014, 45, 479. [CrossRef]

21. Mark, O.; Weesakul, S.; Apirumanekul, C.; Aroonnet, S.B.; Djordjević, S. Potential and limitations of 1D modelling of urban flooding. J. Hydrol. 2004, 299, 284-299. [CrossRef]

22. Thorndahl, S.; Beven, K.J.; Jensen, J.B.; Schaarup-Jensen, K. Event based uncertainty assessment in urban drainage modelling, applying the GLUE methodology. J. Hydrol. 2008, 357, 421-437. [CrossRef]

23. Haghighatafshar, S.; Nordlöf, B.; Roldin, M.; Gustafsson, L.G.; la Cour Jansen, J.; Jönsson, K. Efficiency of blue-green stormwater retrofits for flood mitigation-Conclusions drawn from a case study in Malmö, Sweden. J. Environ. Manag. 2018, 207, 60-69. [CrossRef]

24. Berggren, K.; Olofsson, M.; Viklander, M.; Svensson, G.; Gustafsson, A.-M. Hydraulic Impacts on Urban Drainage Systems due to Changes in Rainfall Caused by Climatic Change. J. Hydrol. Eng. 2012, 17, 92-98. [CrossRef]

25. Crichton, D. The risk triangle. In Natural Disaster Management; Tudor Rose: London, UK, 1999; pp. 102-103, ISBN 0-9536140-1-8.

26. Kron, W. Flood risk = hazard • values $\bullet$ vulnerability. Water Int. 2005, 30, 58-68. [CrossRef]

27. Koks, E.E.; Jongman, B.; Husby, T.G.; Botzen, W.J.W. Combining hazard, exposure and social vulnerability to provide lessons for flood risk management. Environ. Sci. Policy 2015, 47, 42-52. [CrossRef]

28. Schroeder, D.; Pisupati, B. Ethics, Justice and the Convention on Biolgical Divercity; UNEP: Nairobi, Kenya, 2010.

29. Intergovernmental Panel on Climate Change (IPCC). Managing the Risks of Extreme Events and Disasters to Advance Climate Change Adaptation; Cambridge University Press: Geneva, Switzerland, 2012; ISBN 1107025060. 
30. Johnson, C.; Penning-Rowsell, E.; Parker, D. Natural and imposed injustices: The challenges in implementing "fair" flood risk management policy in England. Geogr. J. 2007, 173, 374-390. [CrossRef]

31. Butler, D.; Davies, J.W. Urban Drainage, 3rd ed.; Taylor \& Francis: Abingdon, UK, 2000; ISBN 978-0-203-35167-3.

32. Semadeni-Davies, A.; Hernebring, C.; Svensson, G.; Gustafsson, L.G. The impacts of climate change and urbanisation on drainage in Helsingborg, Sweden: Combined sewer system. J. Hydrol. 2008, 350, 100-113. [CrossRef]

33. Yazdanfar, Z.; Sharma, A. Urban drainage system planning and design - Challenges with climate change and urbanization: A review. Water Sci. Technol. 2015, 72, 165-179. [CrossRef]

34. Torgersen, G.; Bjerkholt, J.T.; Kvaal, K.; Lindholm, O.G. Correlation between extreme rainfall and insurance claims due to urban flooding - Case study fredrikstad, Norway. J. Urban Environ. Eng. 2015, 9, 127-138. [CrossRef]

35. Torgersen, G.; Bjerkholt, J.T.; Lindholm, O.G. Addressing flooding and SuDS when improving drainage and sewerage systems-A comparative study of selected Scandinavian cities. Water 2014, 6, 839-857. [CrossRef]

36. Mailhot, A.; Duchesne, S. Design Criteria of Urban Drainage Infrastructures under Climate Change. J. Water Resour. Plan. Manag. 2010, 136, 201-208. [CrossRef]

37. Swedish Water/Svensk Vatten (SW). Drainage of Runoff and Wastewater-Functional Requirments, Hydraulic Dimensioning and Design of Public Swer System; Publication P110; Swedish Water and Wastewater Accociation (Svensk VAtten): Bromma, Sweden, 2016. (In Swedish)

38. Niemczynowicz, J. Impact of the greenhouse effect on sewerage systems-Lund case study. Hydrol. Sci. J. 1989, 34, 651-666. [CrossRef]

39. Tuyls, D.M.; Thorndahl, S.; Rasmussen, M.R. Return period assessment of urban pluvial floods through modelling of rainfall-flood response. J. Hydroinformatics 2018, 20, 829-845. [CrossRef]

40. Willems, P.; Arnbjerg-Nielsen, K.; Olsson, J.; Nguyen, V.T.V. Climate change impact assessment on urban rainfall extremes and urban drainage: Methods and shortcomings. Atmos. Res. 2012, 103, 106-118. [CrossRef]

41. Schmitt, T.G.; Thomas, M.; Ettrich, N. Analysis and modeling of flooding in urban drainage systems. J. Hydrol. 2004, 299, 300-311. [CrossRef]

42. Green, C. Towards Sustainable Flood Risk Management. Int. J. Disaster Risk Sci. 2010, 1, $33-43$.

43. Olshammar, M.; Christian, B. Vattenskador orsakade av baktryck i avloppssystemet - erfarenheter, regler, hantering och tekniska lösningar (In Swedish). Water Damage Caused by Back Water Pressure in the Sewage System-Experiences, Rules, Management and Technical Solutions; IVL: Stockholm, Sweden, 2012.

44. Grahn, T.; Nyberg, R. Damage assessment of lake floods: Insured damage to private property during two lake floods in Sweden 2000/2001. Int. J. Disaster Risk Reduct. 2014, 10, 305-314. [CrossRef]

45. Burton, E. The compact city: Just or just compact? A preliminary analysis. Urban Stud. 2000, 37, $1969-2001$. [CrossRef]

46. McDermott, M.; Mahanty, S.; Schreckenberg, K. Examining equity: A multidimensional framework for assessing equity in payments for ecosystem services. Environ. Sci. Policy 2013, 33, 416-427. [CrossRef]

47. Grasso, M. A normative ethical framework in climate change. Clim. Chang. 2007, 81, 223-246. [CrossRef]

48. Nancy Fraser. Scales of Justice: Re-Imagining Political Space in a Globalizing World; Columbia University Press: New York, NY, USA, 2009; ISBN 978-0231146814.

49. Olsson, J.; Amaguchi, H.; Alsterhag, E.; Dåverhög, M.; Adrian, P.E.; Kawamura, A. Adaptation to Climate Change Impacts on Urban Storm Water: A Case Study in Arvika, Sweden. Clim. Chang. 2013, 116, 231-247. [CrossRef]

50. Zhou, Q.; Mikkelsen, P.S.; Halsnæs, K.; Arnbjerg-Nielsen, K. Framework for economic pluvial flood risk assessment considering climate change effects and adaptation benefits. J. Hydrol. 2012, 414-415, 539-549. [CrossRef]

51. Soanes, C.; Stevenson, A. Oxford Dictionary of English (ODE); Oxford University Press: Oxford, UK, 2003.

52. Yin, R.K. Case Study Research: Design and Methods; Sage Publishing: Newbury Park, CA, USA, 2002; ISBN 978-1452242569.

53. Blumenthal, B.; Nyberg, L. The impact of intense rainfall on insurance losses in two Swedish cities. J. Flood Risk Manag. 2018, 12, e12504. [CrossRef]

54. SCB, Statistikmyndigheten SCB. Available online: https://www.scb.se/ (accessed on 26 September 2019).

55. Agresti, A. An Introduction to Categorical Data Analysis; John Wiley \& Sons, Inc.: Hoboken, NJ, USA, 2007; ISBN 9780470114759. 
56. Pearson, K.X. On the criterion that a given system of deviations from the probable in the case of a correlated system of variables is such that it can be reasonably supposed to have arisen from random sampling. Lond. Edinb. Dublin Philos. Mag. J. Sci. 1900, 50, 157-175. [CrossRef]

57. Fisher, R.A. Statistical Methods for Research Workers. J. R. Stat. Soc. 1939, 102, 298. [CrossRef]

58. Woodside, A. Case Study Research:Theory, Methods and Practice: Theory, Methods, Practice; Emerald Group Publishing Limited: Bingley, UK, 2010; ISBN 9781849509220.

59. Grahn, T.; Nyberg, L. Assessment of pluvial flood exposure and vulnerability of residential areas. Int. J. Disaster Risk Reduct. 2017, 21, 367-375. [CrossRef]

60. Berggren, K.; Packman, J.; Ashley, R.; Viklander, M. Climate changed rainfalls for urban drainage capacity assessment. Urban Water J. 2014, 11, 543-556. [CrossRef]

61. Sørup, H.J.D.; Davidsen, S.; Löwe, R.; Thorndahl, S.L.; Borup, M.; Arnbjerg-Nielsen, K. Evaluating catchment response to artificial rainfall from four weather generators for present and future climate. Water Sci. Technol. 2018, 77, 2578-2588. [CrossRef]

62. Kleidorfer, M. Uncertain Calibration of Urban Drainage Models. Ph.D. Thesis, University of Innsbruck, Innsbruck, Austria, November 2009.

63. Haghighatafshar, S.; Becker, P.; Moddemeyer, S.; Persson, A.; Sörensen, J.; Aspegren, H.; Jönsson, K. Paradigm shift in engineering of pluvial floods: From historical recurrence intervals to risk-based design for an uncertain future. Sustain. Cities Soc. 2020, 61, 102317. [CrossRef]

64. Postgård, U. Pluviala översvämningar Konsekvenser vid skyfall över tätorter; MSB: Karlstad, Sweden, 2013.

65. Svara, J.H.; Brunet, J.R. Social Equity Is a Pillar of Public Administration. J. Public Aff. Educ. 2018, 11, $253-258$. [CrossRef]

66. Reckien, D.; Creutzig, F.; Fernandez, B.; Lwasa, S.; Tovar-Restrepo, M.; Mcevoy, D.; Satterthwaite, D. Climate change, equity and the Sustainable Development Goals: An urban perspective. Environ. Urban. 2017, 29, 159-182. [CrossRef]

67. Irwin, S.; Howlett, C.; Binns, A.D.; Sandink, D. Mitigation of Basement Flooding due to Sewer Backup: Overview and Experimental Investigation of Backwater Valve Performance. Nat. Hazards Rev. 2018, 19, 04018020. [CrossRef]

68. Regueiro-Picallo, M.; Naves, J.; Anta, J.; Puertas, J.; Suárez, J. Experimental and numerical analysis of egg-shaped sewer pipes flow performance. Water 2016, 8, 587. [CrossRef]

69. Tirado, A.A.; Morales, M.R.; Lobato-Calleros, O. Additional indicators to promote social sustainability within government programs: Equity and efficiency. Sustainability 2015, 7, 9251-9267. [CrossRef]

70. Svensk, V. Allmänna bestämmelser VA (ABVA)-Svenskt Vatten (In Swedish); IVL Svenska miljöinstitutet: Malmö, Sweden, 2009.

71. Douglas, I.; Garvin, S.; Lawson, N.; Richards, J.; Tippett, J.; White, I. Urban pluvial flooding: A qualitative case study of cause, effect and nonstructural mitigation. J. Flood Risk Manag. 2010, 3, 112-125. [CrossRef]

72. Dworkin, R. What is Equality? Part 2: Equality of Resources. Philos. Public Aff. 1981, 10, 283-345.

73. Arthurton, R.S. Marine-related physical natural hazards affecting coastal megacities of the Asia-Pacific region-Awareness and mitigation. Ocean Coast. Manag. 1998, 40, 65-85. [CrossRef]

74. Clément, V.; Rey-Valette, H.; Rulleau, B. Perceptions on equity and responsibility in coastal zone policies. Ecol. Econ. 2015, 119, 284-291. [CrossRef]

75. Fleurbaey, M. Fairness, Responsibility, and Welfare; Oxford University Press: Oxford, UK, 2008; ISBN 9780199215911.

76. Penning-Rowsell, E.; Korndewal, M. The realities of managing uncertainties surrounding pluvial urban flood risk: An ex post analysis in three European cities. J. Flood Risk Manag. 2019, 12, 1-12. [CrossRef]

77. Thorndahl, S.; Schaarup-Jensen, K.; Jensen, J.B. Probabilistic modelling of combined sewer overflow using the First Order Reliability Method. Water Sci. Technol. 2008, 57, 1337-1344. [CrossRef]

78. Deletic, A.; Dotto, C.B.S.; McCarthy, D.T.; Kleidorfer, M.; Freni, G.; Mannina, G.; Uhl, M.; Henrichs, M.; Fletcher, T.D.; Rauch, W.; et al. Assessing uncertainties in urban drainage models. Phys. Chem. Earth 2012, 42-44, 3-10. [CrossRef]

79. Freni, G.; La Loggia, G.; Notaro, V. Uncertainty in urban flood damage assessment due to urban drainage modelling and depth-damage curve estimation. Water Sci. Technol. 2010, 61, 2979-2993. [CrossRef] [PubMed]

80. Beck, M.B. Water quality modelling: A review of uncertainty. Water Resour. Res. 1987, 23, $1393-1442$. [CrossRef] 
81. Becker, P. Sustainability Science; Elsevier: Amsterdam, The Netherlands, 2014; ISBN 9780444627094.

82. Alford, J.; Head, B.W. Wicked and less wicked problems: A typology and a contingency framework. Policy Soc. 2017, 36, 397-413. [CrossRef]

83. Harvey, L.; Comley, J.; Marshall, A.; Edwards, P. Organisational Capacity in Integrated Urban Water Management: The Art of Being. In Proceedings of the 6th International Water Sensitive Urban Design Conference and Hydropolis \#3, Perth, Australia, 5-8 May 2009; Volume 3, pp. 1-9.

84. Johannessen, Å.; Granit, J.J. Integrating Flood Risk, River Basin Management and Adaptive Management: Gaps, Barriers and Opportunities, Illustrated by a Case Study from Kristianstad, Sweden. Int. J. Water Gov. 2015, 3, 5-24.

85. Mostert, E.; Raadgever, G.T. Seven rules for researchers to increase their impact on the policy process. Hydrol. Earth Syst. Sci. 2008, 12, 1087-1096. [CrossRef]

86. Pahl-Wostl, C.; Sendzimir, J.; Jeffrey, P.; Aerts, J.; Berkamp, G.; Cross, K. Managing Change toward Adaptive Water Management through Social Learning. Ecol. Soc. 2007, 12, 30. [CrossRef]

Publisher's Note: MDPI stays neutral with regard to jurisdictional claims in published maps and institutional affiliations.

(C) 2020 by the authors. Licensee MDPI, Basel, Switzerland. This article is an open access article distributed under the terms and conditions of the Creative Commons Attribution (CC BY) license (http://creativecommons.org/licenses/by/4.0/). 